\title{
Rapid diagnostics test for detecting Chagas disease - Breaking barriers to diagnosis access in remote areas
}

\author{
Diego Mendicino* \\ Doctor in Health Sciences. Faculty of Biochemistry and Biological Sciences, National University of the Littoral, Argentina
}

\section{Introduction}

Chagas disease $(\mathrm{CD})$ is a widespread zoonosis in Latin America caused by the flagellate protozoan Trypanosoma cruzi (T. cruzi). It is considered the main Neglected Tropical Disease in the region. The parasite infects 6-9 million people and cause more than 10000 deaths per year [1]. The route of transmission is mainly vector borne through hematophagous triatomine insects (entomological route). Other routes of transmission of quantitatively lower public health significance are transfusion, connatal and digestive routes, and they are responsible for the urbanization and globalization of the disease [2]. For environmental and social reasons, the insect vector persists in the precarious dwellings of scattered and hard to reach rural populations where the prevalence of infection by this route is greater [3]. Entomological T. cruzi transmission persists in the Gran Chaco region, extends over sections of Argentina, Bolivia, and Paraguay, which is considered hyperendemic for CD. Rural populations and indigenous communities in this region have large prevalence rates of $\mathrm{CD}$ infection and very limited access to diagnosis and treatment [4-6].

The infection is often asymptomatic or oligosymptomatic in the acute period. The chronic stage is also silent until, after 20 years or more, cardiac and/or gastrointestinal pathologies appear and reduces life expectancy in approximately one third of the patients. The two drugs (nifurtimox and benznidazole) registered for treatment of CD since the late 1960s and early 1970 s were shown to be especially effective in young age groups during the acute and early chronic phase regardless of transmission mode. Therefore, chemotherapeutic treatment of CD ideally should provide access to diagnosis as early as possible during the life course. However less than $1 \%$ of patients infected with T. cruzi have access to parasiticidal treatment due to lack of diagnosis [7].

During the chronic phase, the infection is confirmed by demonstrating the host antibodies against the parasite. World Health Organization recommends the simultaneous use of two serological tests with different principles or that detect antibodies against different specific antigens for the diagnosis of $\mathrm{CD}$ at the chronic stage. The results of the two tests must be coincidentally positive. In cases of discrepancy (a positive and a negative test), a third test should be conducted to confirm or rule out infection [8].

The most commonly used conventional serological tests (CST) are the enzyme-linked immunosorbent assay (ELISA) and indirect hemagglutination (IHA) and, in case of discrepancy, indirect immunofluorescence (IFl). There are currently various serological diagnostic techniques being evaluated, each of them using different principles [9]. However, conducting these tests requires equipped laboratories and human resources trained in biochemical analysis [10]. Fluoroscence microscope and dark room are also needed for IFI technique. The transmission occurs most often in populations far from urban centers, where access to health coverage is reduced and traveling to locations where more complex services are available is very difficult. It is also common in some areas in developing countries for births to occur without any control and, therefore, that children do not have access to laboratory testing for early detection of congenital transmission. Likewise, in unexpected situations in which an emergency transfusion is required, sometimes people must choose between the risk involved in the delay caused by the transfer of the patient and the risk of using blood unscreened for Chagas.

In response to the lack of availability in the field of laboratories with the necessary equipment to diagnose this infection, some authors have proposed, both by clinical interest and for population studies, several alternatives to perform CST in areas distant from health centers, such as collecting blood samples on filter paper [11], preserving blood in glycerin [12] and collecting oral mucosal trasudate specimens [13]. Although these studies yielded good results, they required transport of all the samples to the laboratory and the need to return to the field for venous blood sampling of positive patients, with the inherent expenses, loss of patient follow-up and delay in results.

Due to the difficulties described above, there is the need for techniques that can be used in the field, with no highly complex requirements such as specialized personnel and instruments, but that deliver results quickly and reliably.

Immunochromatograpic tests with colloidal gold, commonly named rapid diagnostic tests (RDT), have been recently developed for diagnosis of physiological conditions (e.g. pregnancy tests) and infectious and noninfectious diseases. RDT have some advantages, including technical simplicity, conservation of the kits at room temperature, possibility of individual application, and rapid reading of results with no need for an equipped laboratory. These characteristics make them very useful as screening tests in distant sites; however, a positive result must be confirmed later in a laboratory by CST. The low sensitivity values obtained with RDT by different authors suggest that they would be useful only if used in parallel with a CST, rendering them less useful in the field [14-16]. Diagnosis sensitivity can be enhanced by performing tests simultaneously on a single sample. The simultaneous use of two different RDTs with the same sample allows the health

${ }^{\star}$ Correspondence to: Diego Mendicino, Faculty of Biochemistry and Biological Sciences, National University of Littoral. Ciudad Universitaria, Paraje El Pozo, Santa Fe (3000), Argentina, E-mail: diegomendicino@hotmail.com

Received: July 05, 2019; Accepted: July 12, 2019; Published: July 16, 2019 
professionals to obtain a complete diagnosis of CD in remote areas and without laboratory equipment, thereby complying with international recommendations. Given the short time involved in the whole process, including blood sampling, processing and RDT reading, the results can be returned almost immediately. Thus, only discordant samples, which represent a very low percentage, would have to be transported to a laboratory in a Health Center to be resolved using a third method (IHA, ELISA or IFI). On the other hand, in middle complexity laboratories where HAI and ELISA can be performed, RDT could be used to define discordant result in replace of IFI, due to the high specificity demonstrated by different authors [14-16]. Increasing access to highquality serodiagnosis of marginalized rural populations, the RDTs will provide them the opportunity of treatment and prevent the associated pathologies.

\section{References}

1. Hotez PJ, Alvarado M, Basañez MG, Bolliger I, Bourne R, et al. (2014) The global burden of disease study 2010: interpretation and implications for the neglected tropical diseases. PLoS Negl Trop Dis 8: e2865. [Crossref]

2. Rassi A Jr, Rassi A, Marin-Neto JA (2010) Chagas disease. Lancet 375: 1388-1402. [Crossref]

3. Briceño-León R, Méndez Galván J (2007). The social determinants of Chagas disease and the transformations of Latin America. Mem Inst Oswaldo Cruz 102: 109-112. [Crossref]

4. Colussi C, Stafuza M, Denner S, Nepote M, Mendicino D (2016) Epidemiology of Chagas disease in mocovies and creole communities in southern Argentine Chaco. Salud Publica Mex 58: 3-4.

5. Mendicino D, Stafuza M, Colussi C, Achkar G, Garnero N, et al. (2015) Chagas pediátrico en áreas rurales de la Provincia de Santa Fe. Rev argent salud publica 6: $14-18$.
6. Mendicino D, Colussi C, Stafuza M, Manattini S, Montemagiore S, et al. (2019). Seroprevalencia de Chagas en mayores de 14 años de áreas rurales del Chaco Santafesino. Rev Fac Cien Med Univ Nac Córdoba 76: 47-51. [Crossref]

7. Ribeiro I, Sevcsik AM, Alves F, Diap G, Don R, et al. (2009) New, improved treatments for Chagas disease: From the R\&D pipeline to the patients. PLoS Negl Trop Dis 3: e484. [Crossref]

8. World Health Organization. Fact sheet Chagas. www.who.int/mediacentre/factsheets/ fs340/ (2017, accessed 06 June 2017).

9. Afonso AM, Ebell MH, Tarleton RL (2012). A Systematic Review of High Quality Diagnostic Tests for Chagas Disease. PLoS Negl Trop Dis 6: e1881. [Crossref]

10. Holguín A, Norman F, Martín L, Mateos M, Chacón J, et al. (2013) Dried blood as an alternative to plasma or serum for Trypanosoma cruzi IgG detection in screening programs. Clin Vaccine Immunol 20: 1197-1202. [Crossref]

11. Arrieta R, Daquino B, Rosso N, Ferreras M, Juárez N (2004). Evaluación de una metodología de tamizaje en la enfermedad de Chagas en San Luis, Argentina. Salud Publica Mex 46: 430-437.

12. Moretti E, Basso B, Gil P, Vaca B, Jacqueline J, et al. (2004). Detección de anticuerpos para Chagas y Toxoplasmosis en trasudado mucoso oral. Acta Bioquím Clín Latinoam 38: 159-163. [Crossref]

13. Reithinger R, Grijalva M, Chiriboga R, Alarcón de Noya B, et al. (2010) Rapid Detection of Trypanosoma cruzi in Human Serum by Use of a Immunochromatographic Dipstick Test. J Clin Microbiol 48: 3003-3007. [Crossref]

14. Sanchez-Camargo C, Albajar-Viñas P, Wilkins P, Nieto J, Leiby D, et al. (2014) Comparative evaluation of 11 commercialized Diagnostic Tests for detecting Trypanosoma cruzi antibodies in serum banks in endemic and non-endemic areas. $J$ Clin Microbiol 52: 2506-2512. [Crossref]

15. Mendicino D, Stafuza M, Colussi C, Streiger M, Moretti E, et al. (2014) Diagnostic reliability of an immunochromatographic test for Chagas' disease screening at a primary health care centre in a rural endemic area. Mem Inst Oswaldo Cruz 109: 984988. [Crossref]

16. Mendicino D, Colussi C, Moretti E (2019) Simultaneous use of two rapid diagnostic tests for the diagnosis of Chagas disease. Trop Doct 49: 23-26. [Crossref]

Copyright: ( 2019 Mendicino D. This is an open-access article distributed under the terms of the Creative Commons Attribution License, which permits unrestricted use, distribution, and reproduction in any medium, provided the original author and source are credited. 